\title{
Secondary Amyloidosis Associated with Castleman's Disease
}

\author{
Katsuhiro Tanaka, Masakazu Horita, Hitoshi Shibayama, Masataka Seike, Yasuko Itoh, \\ Kazuyuki Hamaguchi, Yasufumi Sato, Toshiie SaKata and Tetsuya IshidA*
}

\begin{abstract}
A rare case of secondary amyloidosis associated with Castleman's disease is reported. A 53year-old woman was referred for investigation of proteinuria. Biopsy specimens from kidney and gastric mucosa revealed numerous amyloid deposits, defined as AA amyloidosis by immunohistological staining. Castleman's disease was found in the abdomen as the primary disease for the amyloidosis. Although the urinary protein was somewhat reduced and the inflammatory findings were improved after removal of the lymphoma, renal insufficiency progressed and hemodialysis was begun.
\end{abstract}

(Internal Medicine 34: 122-126, 1995)

Key words: serum amyloid protein A, renal insufficiency

\section{Introduction}

Secondary amyloidosis is caused mainly by chronic inflammatory diseases such as rheumatoid arthritis and tuberculosis. Systemic amyloidosis with Castleman's disease was first reported by Plavnick et al in 1980 (1) and since then only eight cases (1-7) have been reported. However in only two cases amyloidosis was confirmed to be secondary $(2,3)$. Here, we report the clinical course of a patient with systemic and secondary amyloidosis associated with intraabdominal Castleman's disease of the plasma cell type. Although surgical removal of the lymphoma improved her clinical manifestations and laboratory findings, it did not halt the progression of renal insufficiency.

\section{Case Report}

A 53-year-old Japanese woman had suffered from bilateral leg edema since 1984. In 1988, she was found to have hypothyroidism and since then had been administered thyroxine. In 1990 her leg edema progressed and she was admitted to our hospital in August 1990.

A physical examination on admission revealed hypertension $(174 / 94 \mathrm{mmHg})$, low grade fever $\left(37.4^{\circ} \mathrm{C}\right)$, diffusely hard struma and bilateral leg edema. No mass was palpated in the abdomen. Laboratory findings (Table 1) showed proteinuria, anemia, elevation of the erythrocyte sedimentation rate (ESR), hypoalbuminemia $(2.1 \mathrm{~g} / \mathrm{dl})$, polyclonal gammopathy and renal insufficiency (blood uremic nitrogen; BUN $26 \mathrm{mg} / \mathrm{dl}$, creatinine; $\mathrm{Cr} 1.9 \mathrm{mg} / \mathrm{dl})$. Serological examination showed elevation of serum C-reactive protein (CRP). Creatinine clearance was severely reduced.

Marked amyloid deposits were observed on renal biopsy. The biopsy of gastric mucosa also revealed amyloid deposits. The specimen from gastric mucosa was stained positively by antibody against SAA (serum amyloid protein A) (Fig. 1). She was diagnosed to have systemic and secondary amyloidosis. On echocardiogram, diffuse thickening of the left ventricular wall (IVS thickness $13 \mathrm{~mm}$ ) with a "granular sparkling pattern" was found and its movement was decreased, suggesting cardiac amyloidosis. Hypothyroidism could be due to amyloid deposition since the patient had no thyroid autoantibodies and no particular findings on echo or CT. On abdominal CT, a clearly bordered low density mass was found adjacent to the body of pancreas (Fig. 2). Duodenography revealed that the mass compressed the fourth portion of the duodenum (Fig. 3).

On abdominal exploration, the mass was found in the left upper peritoneal space near Treitz' ligament. It had a stalk extending from the retroperitoneal space and was $5 \times 5 \times 5 \mathrm{~cm}$ in diameter, circumscribed and capsulated (Fig. 4). The mass was removed and microscopic examination demonstrated numerous lymphoid follicles with various sized germinal centers. Between the lymphoid follicles, were many plasma cells without pleomorphism (Fig. 5A, B). These findings were compatible with Castleman's disease of the plasma cell type.

After resection of the mass, low grade fever, elevation of

From the First Department of Internal Medicine and *the Department of Pathology, Medical University of Oita, Oita

Received for publication May 13, 1994; Accepted for publication October 5, 1994

Reprint requests should be addressed to Dr. Katsuhiro Tanaka, the First Department of Internal Medicine, Medical University of Oita, 1-1 Idaigaoka, Hasamacho, Oita-gun, Oita 879-55 


\section{Castleman's Disease and Amyloidosis}

Table 1. Laboratory Data on Admission

\begin{tabular}{|c|c|c|c|}
\hline \multicolumn{4}{|l|}{ (Urine) } \\
\hline Protein & $(+++)$ & Total cholesterol & $157 \mathrm{mg} / \mathrm{dl}$ \\
\hline Glucose & $(-)$ & Triglyceride & $85 \mathrm{mg} / \mathrm{dl}$ \\
\hline Occult blood & $(+)$ & Blood urea nitrogen & $26 \mathrm{mg} / \mathrm{dl}$ \\
\hline Sediments : & & Creatinine & $1.9 \mathrm{mg} / \mathrm{dl}$ \\
\hline Red blood cells & $5-10 / \mathrm{HPF}$ & Uric acid & $9.4 \mathrm{mg} / \mathrm{dl}$ \\
\hline White blood cells & $1-2 / \mathrm{HPF}$ & $\mathrm{Na}$ & $145 \mathrm{mEq} / \mathrm{l}$ \\
\hline Cast & $(-)$ & $\mathrm{K}$ & $4.2 \mathrm{mEq} / \mathrm{l}$ \\
\hline \multicolumn{2}{|c|}{$\begin{array}{l}\text { (Erythrocyte sedimentation rate) } 80 \mathrm{~mm} / 1 \mathrm{~h} \\
\text { (CBC) }\end{array}$} & Chloride & $105 \mathrm{mEq} / \mathrm{l}$ \\
\hline$(\mathrm{CBC})$ & 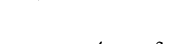 & Serum iron & $49 \mu \mathrm{g} / \mathrm{dl}$ \\
\hline Red blood cells & $353 \times 10^{4} / \mathrm{mm}^{3}$ & & \\
\hline Hemoglobin & $8.5 \mathrm{~g} / \mathrm{dl}$ & & \\
\hline Hematocrit & $28.0 \%$ & (Serology) & \\
\hline Platelets & $33.8 \times 10^{4} / \mathrm{mm}^{3}$ & C-reactive protein & $9.7 \mathrm{mg} / \mathrm{dl}$ \\
\hline \multirow[t]{2}{*}{ White blood cells } & $5,080 / \mathrm{mm}^{3}$ & Immunoglobulin G & $2,480 \mathrm{mg} / \mathrm{dl}$ \\
\hline & & Immunoglobulin A & $402 \mathrm{mg} / \mathrm{dl}$ \\
\hline (Blood chemistry) & & Immunoglobulin $\mathrm{M}$ & $335 \mathrm{mg} / \mathrm{dl}$ \\
\hline Total Protein & $6.7 \mathrm{~g} / \mathrm{dl}$ & Antimicrosomal antibody & $(-)$ \\
\hline Albumin & $30.6 \%$ & Antithyroglobulin antibody & $(-)$ \\
\hline$\alpha_{1}$-globulin & $5.2 \%$ & & \\
\hline$\alpha_{2}$-globulin & $15.0 \%$ & & \\
\hline B-globulin & $9.8 \%$ & (Thyroid function) & \\
\hline$\gamma$-globulin & $39.4 \%$ & Free triiodothyronine & $1.1 \mathrm{pg} / \mathrm{ml}$ \\
\hline Total bilirubin & $0.3 \mathrm{mg} / \mathrm{dl}$ & Free thyroxine & $0.8 \mathrm{ng} / \mathrm{dl}$ \\
\hline Aspartate aminotransferase & $21 \mathrm{IU} / 1$ & Thyroid stimulating hormone & $3.7 \mu \mathrm{U} / \mathrm{ml}$ \\
\hline Alanine aminotransferase & $6 \mathrm{IU} / \mathrm{l}$ & & \\
\hline Alkaline phosphatase & $205 \mathrm{IU} / 1$ & (Urine chemistry and renal func & ction) \\
\hline$\gamma$-Glutamyltranspeptidase & $15 \mathrm{IU} / \mathrm{l}$ & Urine protein & 2.7 g/day \\
\hline Lactate dehydrogenase & $514 \mathrm{IU} / \mathrm{l}$ & Creatinine clearance & $21.3 \mathrm{ml} / \mathrm{min}$ \\
\hline
\end{tabular}

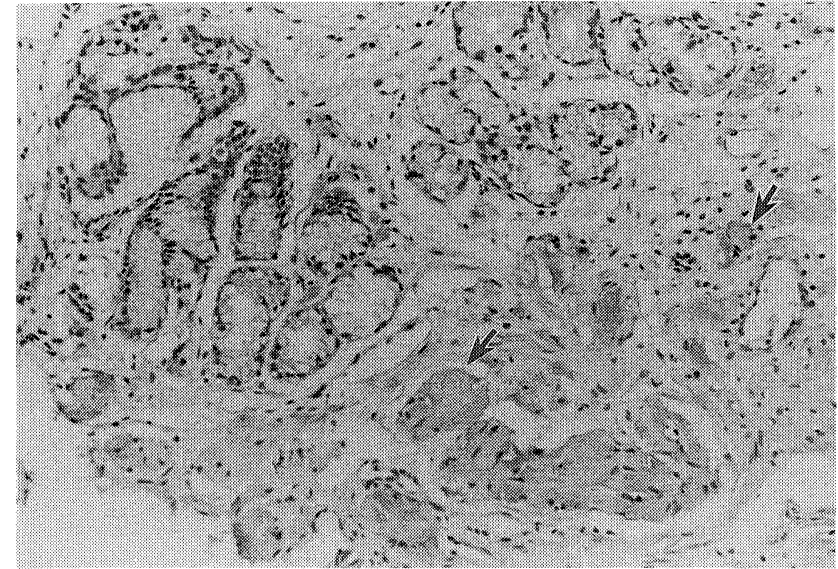

Fig. 1. Gastric mucosa biopsy specimen stained by antibody against SAA. Positively stained lesions are seen in propria and around blood vessels (arrow) $(\times 250)$.

ESR, hypoalbuminemia, elevation of serum CRP and polyclonal gammopathy were all improved and proteinuria was reduced. But renal insufficiency progressed and 20 months after the operation hemodialysis was begun (Fig. 6).

\section{Discussion}

In this case, secondary amyloidosis was diagnosed by posi-

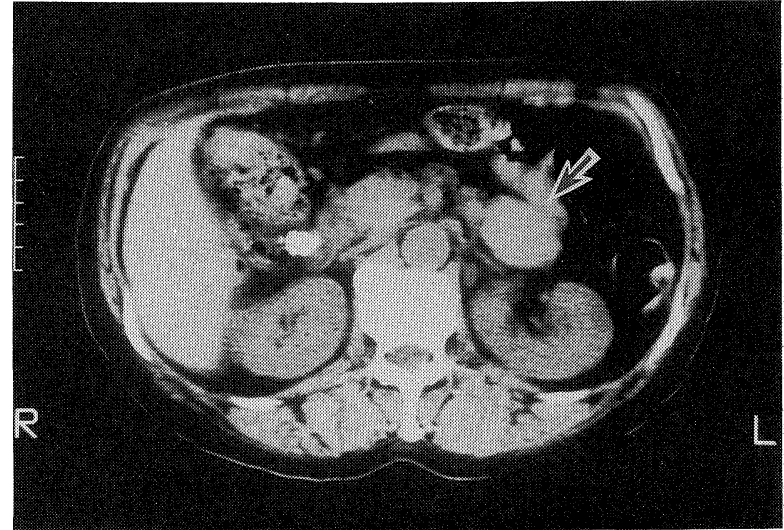

Fig. 2. Abdominal CT. There is an isodense mass at the back of pancreas body (arrow).

tive staining with antibody against SAA. Secondary amyloidosis in this case was assumed to be caused by Castleman's disease, because no other cause for secondary amyloidosis could be found and removal of the lymphoma improved various manifestations and inflammatory laboratory findings.

Castleman's disease was first described by Castleman et al in 1956 (8) and it is considered to be a hamartoma or hyperplasia of the lymphoid tissue. Histologically it is subdivided into hyaline-vascular type (HV type), plasma cell type (PC type) and 


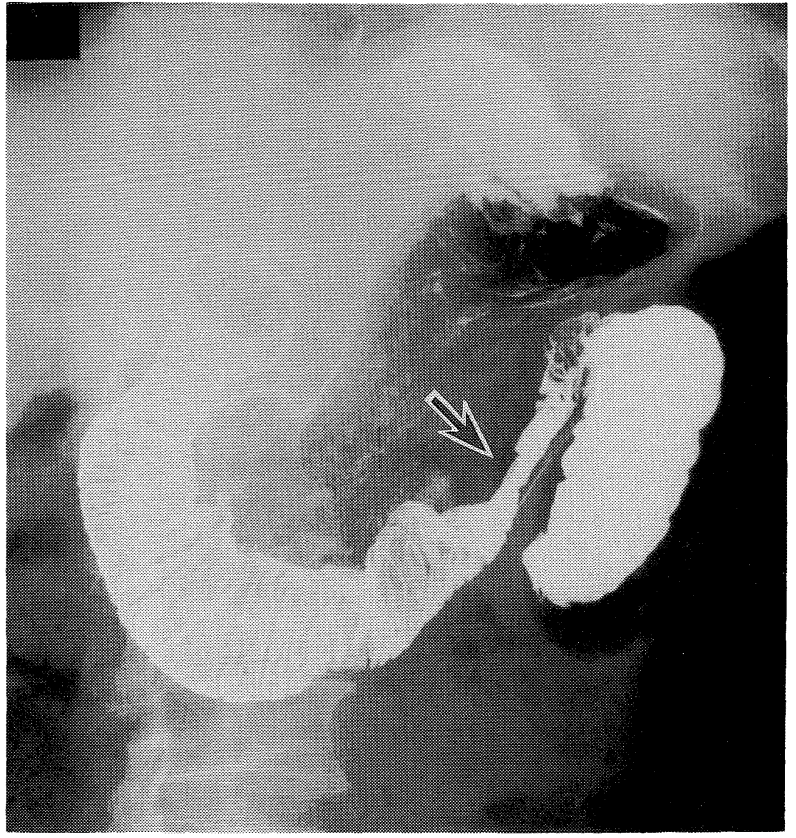

Fig. 3. Duodenography. The fourth portion of the duodenum is compressed by a extraluminal mass (arrow).

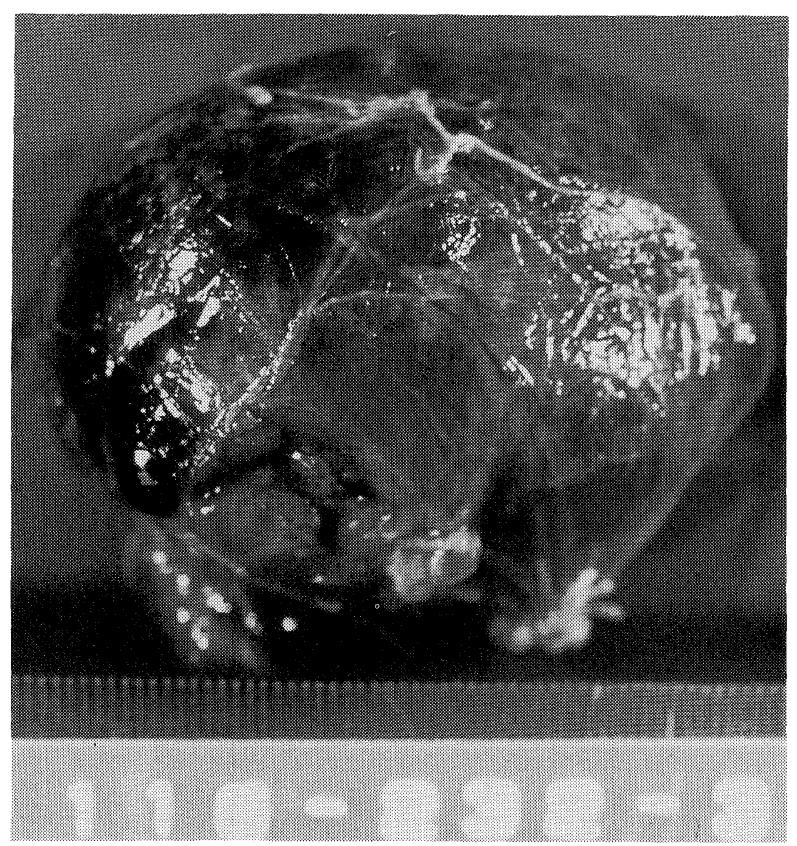

Fig. 4. Removed abdominal mass (macroscopic). The mass is $5 \times 5 \times 5$ $\mathrm{cm}$ in size, circumscribed and capsulated.

mixed type. HV type is more frequent and found mostly incidentally in the mediastinum. While HV type stays asymptomatic, PC type and mixed type occur in various lesions and are accompanied with generalized manifestations such as fever, sweating, elevation of ESR, anemia, and hypergamma-
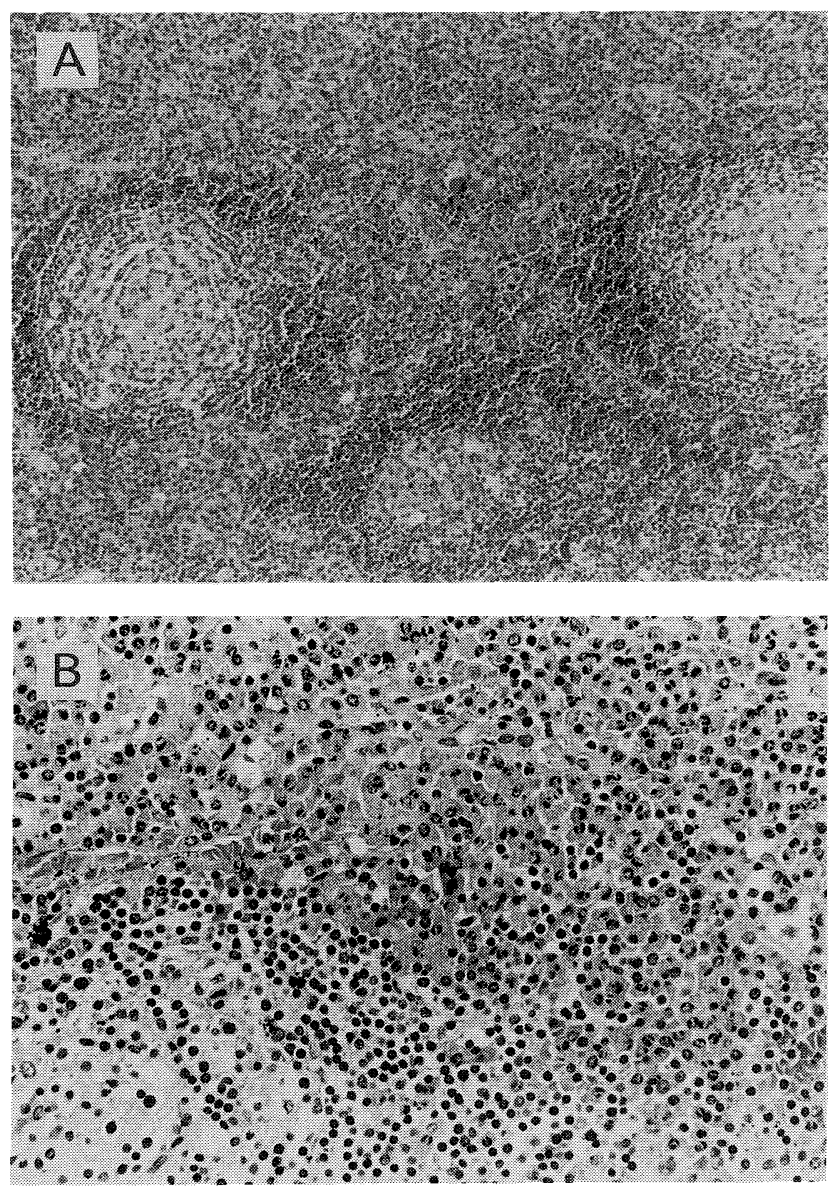

Fig. 5. Removed abdominal mass (microscopic). There are numerous lymphoid follicles (A: HE stain, $\times 40$ ) and between them are many plasma cells without pleomorphism (B: HE stain, $\times 250$ ).

globulinemia. It has been considered an immunological reaction to the disease.

In previously reported cases of systemic amyloidosis with Castleman's disease, they were mostly PC type (1-7). In 1980 Plavnick et al reported systemic amyloidosis with an immunoblastic lymphadenopathy, but it was not defined whether the amyloid was AA type or not (1). In 1982 Bonneau et al reported a case of angiofollicular lymph node hyperplasia (PC type) accompanied with renal amyloidosis, in which the amyloid was defined as AA type (2).

SAA, the precursor of the AA type of amyloid, is one of the acute phase proteins in inflammation and its production is enhanced by interleukin-6 (IL-6) in hepatocytes $(9,10)$. It was revealed that large amounts of IL- 6 are produced in the germinal centers of Castleman's disease (11). Therefore secondary amyloidosis in Castleman's disease can be caused by overproduction of SAA due to IL-6 from the lymphoma. In the present case, we did not measure serum SAA level, but it was assumed to fall after the removal of the lymphoma because it usually is correlated with the serum C-reactive protein level (12).

Six cases of systemic and possibly secondary amyloidosis 


\section{Castleman's Disease and Amyloidosis}
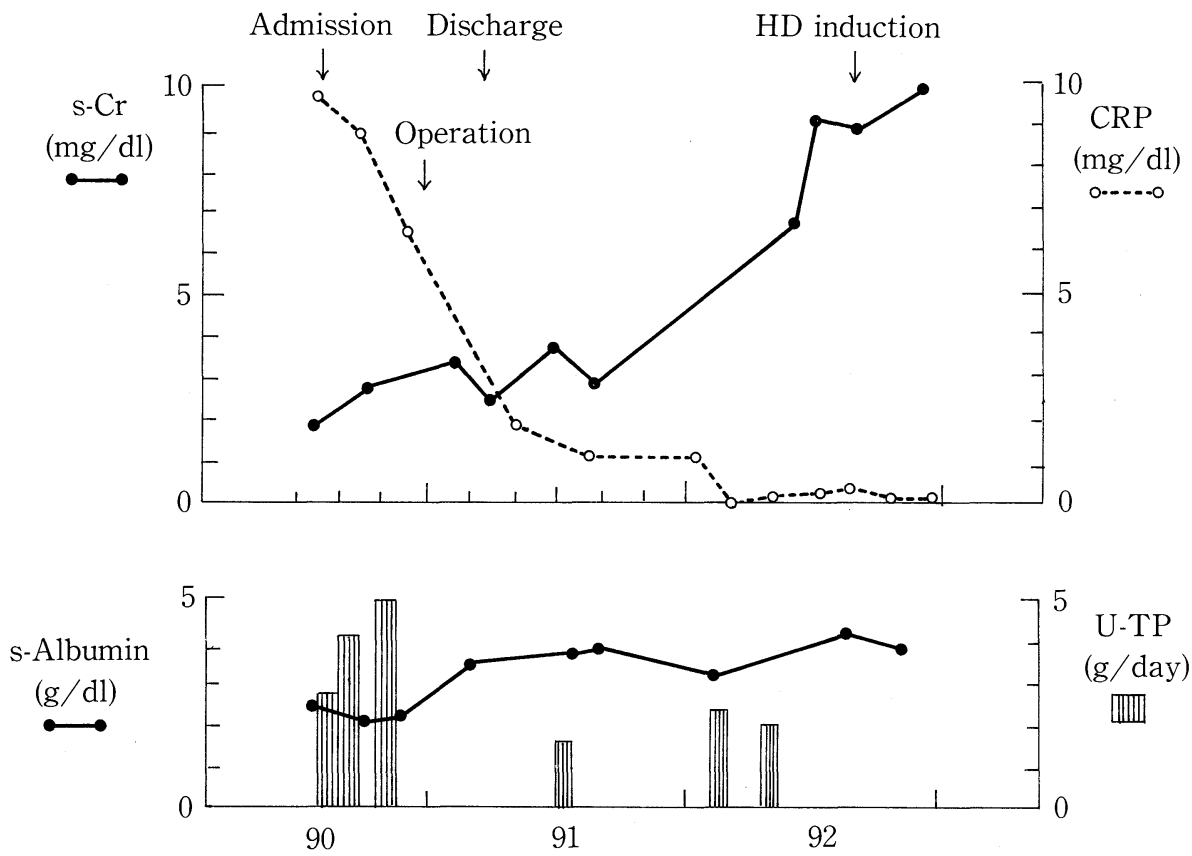

Fig. 6. Clinical course.

s-Cr: serum creatinine, HD induction: hemodialysis induction, U-TP: urine total protein, CRP: C-reactive protein.

Table 2. Previous Reports of Castleman's Disease (PC Type) with Amyloidosis

\begin{tabular}{|c|c|c|c|c|c|c|c|}
\hline Age, & Sex & Histology/Location & Nephrotic syndrome & Type of amyloid & Therapy & Prognosis & Reference \\
\hline 21 & M & PC, peripheral & + & Not described & Not particular & Death & $\# 1$ \\
\hline 23 & $\mathrm{~F}$ & PC, mesenteric LN. & - & Not described & Removal & Cured & \#4 \\
\hline 36 & M & PC, mesenteric LN. & + & AA & Removal & Cured & $\# 2$ \\
\hline 20 & M & PC, location unknown & + & Not described & Not described & Not described & $\# 5$ \\
\hline 52 & M & PC, mesenteric LN. & + & Not described & PSL, melpharan & $\begin{array}{l}\text { Escaped } \\
\text { hemodialysis }\end{array}$ & \#6 \\
\hline 39 & M & PC, peripheral & + & AA & Not described & Death & $\# 3$ \\
\hline
\end{tabular}

PC: plasma cell type.

associated with Castleman's disease have been reported (Table 2). Most of these cases had nephrotic syndrome due to renal amyloidosis. Three of the six cases showed improvement in renal insufficiency and/or other manifestations by treatment of the lymphoma $(2,4,6)$. One died of another disease (1), and in the others their outcomes were not described in detail $(3,5)$. Bonneau et al first reported a case in which proteinuria and various hematologic disturbances were improved after treatment of the lymphoma (2). Chan et al reported a case in which chemotherapy was effective in improving renal insufficiency and hemodialysis was not necessary (6). In the present case, however, removal of the lymphoma did not improve the renal insufficiency. It is possible that severe amyloid deposition in the kidneys in secondary amyloidosis may not be fully reversed by treatment of causative diseases.

\section{References}

1) Plavnick L, Weiner P, Pevzner S. Amyloidosis in immunoblastic lymphadenopathy. Israel J Med Sci 16: 599, 1980

2) Bonneau R, Paquin F, Giroux L. Angiofollicular lymph node hyperplasia of the plasma cell type with nephrotic syndrome and systemic amyloidosis; an unusual association. Lab Invest 10A: 46, 1982.

3) Yago K, Ohno T, Kanoh T. Giant lymph node hyperplasia (Castleman's lymphoma). Nihon-Rinsho-Meneki-Gakkai-Zasshi (Jpn J Immun) 12(5): 502, 1989 (in Japanese)

4) Garcia-San Miguel J, Rczman C, Palacin A, Nomdedeu B. Mesenteric hyaline plasma cell lymph node hyperplasia with amyloid deposits. Arch 


\section{TANAKA et al}

Intern Med 141: 261, 1981.

5) Shimada H, Kanoh T, UchinoH. Multicentric plasma cell type Castleman's lymphadenopathy with nephrotic syndrome. Nihon-Naika Gakkai-Zasshi (J Jpn Soc Int Med) 75: 681, 1986 (in Japanese).

6) Chan CW, Hilary H, Keller J. Giant lymph node hyperplasia with unusual clinicopathologic features. Cancer 53: 2135, 1984.

7) West KP, Morgan DR, Lauder I. Angiofollicular lymph node hyperplasia with amyloidosis. Postgrad Med J 65: 108, 1989.

8) Castleman B, Inverson L, Menendez VP. Localized mediastinal lymph node hyperplasia resembling thymoma. Cancer 9: 822, 1956.

9) Castell JV, Gomez-Lechon MJ, David M, Andus T, Geiger T. Interleukin6 is the major regulator of acute phase protein synthesis in adult human hepatocytes. FEBS Lett 242: 237, 1989.

10) Monshage HJ, Roelofs HM, van Pelt JF, Hazenberg BP. The effect of interleukin-1, interleukin- 6 and its interrelationship on the synthesis of serum amyloid $\mathrm{A}$ and $\mathrm{C}$ reactive protein in primary cultures of adult human hepatocytes. Biochem Biophys Res Commun 155: 112, 1988.

11) Nishimoto N. Pathogenic significance of interleukin-6 in Castleman's lymphoma. Osaka-Daigaku-Igaku-Zasshi (Osaka Univ Med Asso) 41: 143, 1989 (Abstract in English).

12) Yataka M, Yamada T. Biomedical tests in blood and urine for amyloidosis. Nipponrinsho (Japanese Journal of Clinical Medicine) 49: 826, 1991 (in Japanese). 